\title{
Безперервна освіта як вектор розвитку інформаційного суспільства
}

\author{
Н. О. Половая, Національний авіаційний університет
}

Досліджуються особливості розвитку системи вищої освіти в умовах індустріального та постіндустріального суспільства. В даному контексті освіта розглядається як один з найважливіших чинників соціального розвитку, що методологічно пов'язано з концепціями «інформаційного суспільства», «технотронної ери» тощо. Аналізується ідея безперервної освіти, головною метою якої є розвиток людини як особистості, суб'єкта діяльності та спілкування на протязі всього іiі життя. Зазначається, що безперервна освіта є всеохоплюючою за своєю сутністю, індивідуальна за часом, темпами та спрямованісттю, що дає кожному рівні права та можливості реалізації свого власного потенціалу, отримання знань та поповнення їх протягом всього життя. Досліджується історія становлення концепту «безперервна освіта». В статті також розглядаються принципи та види безперервної освіти, а саме формальне навчання, неформальне навчання, позаформальне навчання. Аналізується структура безперервної освіти, де виділяють дві підсистеми - основну і додаткову освіту. А в свою чергу, основна і додаткова освіта може бути загальною і професійною. Отже, виходить чотири підсистеми освіти: основна загальна, основна професійна, додаткова загальна, додаткова професійна. Вказується, що зв'язок між елементами підсистеми основної освіти будуються за принципом ієрархії, кожна наступна ланка надає освіту більш високого рівня. Акцентується увага і на важливості в контексті формування системи безперервної освіти сворення стратегії інформаційно-інноваційного освітнього середовища, яка забезпечує відкритий доступ до програм навчання різного рівня, розробку та використання основ віртуального навчання як важливого способу розширення доступу до будь-якої освіти.

Ключові слова: система вищої освіти; безперервна освіта; інформатизація; функціональний підхід

\section{Continuing education as a vector of information society development}

\section{N. A. Polovaya, National aviation university}

The article investigates features of higher school development in industrial and post-industrial society. In this context the education is considered as one of the most important factors of social development, that is methodologically connected with concepts of "information society", "technetronic epoch" etc. The idea of continuing education is analyzed, which main goal is development of a person as a subject of activity and communication during all his life. Continuing education is noted to be broad by its essence, individual by its time, speed and direction, and it gives everyone equal rights and possibilities to realize his own potential, gather new knowledge and enlarge it during all his life. History of concept "continuing education" formation is studied. Also the article contains discussion of principles and types of continuing education such as formal education, informal education, out-formal education. Structure of continuing education is analyzed where two subsystems are divided - main and additional education. In their turn main and addition educations can be general and professional. Thus, there are four subsystems of the education: main general, main professional, additional general, additional professional. It is specified that connection among the elements of main education subsystem is built on the principle of hierarchy when each next chain provides education of higher level. Also attention is pointed on the necessity of creation of information-innovative environment strategy in the context of continuing education system formation, that enables access to the educative programs of different levels, development and usage of virtual education bases as a necessary way to enlarge access to any education.

In the conditions of formation of society, the question of the formation of new models of education is being updated, among which the model of continuous education is one of the most actual. The problem of continuous education can easily be divided into two major spheres. The latter is connected with the construction of the system of continuous education as an element of social practice, which is connected with the process of absorbing the people of a new life, social and professional experience. In the second case, it is very important to create a strategy for informational and innovative education (informatization of education), which provides an open access to the programs at different levels of education, the development and use of the basis of virtual learning as an essential way of extending the process to all kinds of secondary education - primary, secondary, professional and postgraduate.

Keywords: system of higher education; continuing education; informatization; functional approach

\section{Непрерывное образование как вектор развития информационного общества}

\section{Н. А. Половая, Национальный авиационный университет}

Используются особенности развития системы высшего образования в условиях индустриального и постиндустриального общества. В данном контексте образование рассматривается как один из важнейших факторов социального развития, что методологически связано с концепциями «информационного общества», «технотронной эры». Анализируется идея беспрерывного образования, главной целью которой есть развитие человека как личности, субъекта деятельности и общения на протяжении всей его жизни. Отмечается, что беспрерывное образование является всеохватывающим по своей сущности, индивидуальное по времени, темпами и направлениями, что дает каждому равные права и возможности реализации своего собственного потенциала, получение знаний и пополнения их на протяжении всей жизни. Исследуется история становления концепта «беспрерывное образо- 
вание». В статье также рассматриваются принципы и виды беспрерывного образования, а именно формальное обучение, неформальное обучение, поза формальное обучение. Анализируется структура беспрерывного образования, где выделяют две подсистемы - основное и дополнительное образование. А в свою очередь, основное и дополнительное образование может быть общим и профессиональным. Итак, выходит четыре подсистемы образования: основная общая, основная профессиональная, дополнительная общая, дополнительная профессиональная. Указывается, что связь между элементами подсистемы основного образования строятся за принципом иерархии, каждое следующее звено придает образованию более высокого уровня. Акцентируется внимание и на важности в контексте формирования системы беспрерывного образования создание стратегии информационно-инновационной образовательной среды, которая обеспечивает открытый доступ к программам обучения разного уровня, разработку и использование основ виртуального обучения как важного способа расширения доступа к любому образованию.

Ключевые слова: система высшего образования; беспрерывное образование; информатизация; функциональный подход

Постановка проблеми.

Уучасні системи вищої освіти як на Заході, так і в Україні формуються сьогодні у рамках індустріального суспільства 3 притаманними йому модернізаційними орієнтаціями. Наука перетворюється на самостійний соціальний інститут 3 усіма притаманними йому атрибутами та розвиненою структурою. Змінюється ідеологічна і цільова основа науки, у якій починає домінувати практично-технологічна орієнтація. Відповідно до неї відбуваються зміни в ієрархії академічного знання, де найвище місце посідають дисципліни природничого циклу, що найтісніше пов'язані з матеріальним виробництвом. Перетворення науки на безпосередньо продуктивну силу вимагало також якісно нової, порівняно 3 попереднім досвідом, підготовки фахівців. Уже в першій половині XX ст. вища школа набуває типового оформлення як інститут індустріального суспільства, управління, ресурсне забезпечення та функціонування якого багато в чому збігаються 3 відповідними організаційно-управлінськими характеристиками індустріального підприємства. Головним завданням вищої школи стає підготовка фахівців для потреб суспільної практики.

Найкращі ж у світовому порівнянні університети, інститути, факультети вже 3 давніх часів $є$ єдиними науково-виробничими комплексами, де викладачі витрачають більше половини свого робочого часу на науково- дослідну роботу. У розвинутих країнах світу більша частина науководослідних розробок виконується саме у вищій школі (55 \% у Японіі, 60 \% у США та Німеччині, понад 90 \% у Франції та Великій Британіï). Внаслідок цього вища школа як заклад, що насамперед обслуговує потреби виробництва, набуває конкретно-прикладного, практичного характеру і що далі, то більше актуалізується потреба в безпрервності. Нагальна потреба держави та суспільства в безперервній освіті своїх громадян стала більше усвідомлюватися як актуальна проблема, починаючи 3 другої половини ХX століття, і це пов'язано 3 бурхливим розвитком науково-технічної революції, висунутими нею вимогами до характеру і змісту трудової діяльності.
Система безперервної освіти стала розглядатися як сукупність багатьох проблем: від організаційної та технічної модернізації процесу освіти до соціально-психологічного та духовно-морального виховання особистості. Головною ж передумовою становлення і розвитку безперервної освіти стали інформаційні технології.

\section{Аналіз досліджень і публікацій.}

Витоки ідеї безперервної освіти можна знайти вже у стародавніх філософів - Конфуція, Сократа, Аристотеля, Солона, Платона, Сенеки. 3 економічної точки зору важливість і необхідність розвитку безперервної освіти в індустріально розвинутих країнах обгрунтовується за допомогою концепції «людського капіталу» (Т. Шульц, Г. Беккер, У. Боуен та ін.), а також взаємоконвертованості економічного, соціального і культурного капіталів (П. Бурдьє). Перша ж серйозна наукова розробка теоретичних основ безперервної освіти була здійснена такими вченими, як П. Ленгранд, Е. Фор, Р. Даве, Х. Гуммель, М. Д. Кареялі, Ф. Кумбс, Г. Коптаж.

Мета дослідження - розглянути особливості формування системи безперервної системи освіти в контексті парадигмальних трансформацій і формування інформаційного суспільства.

Виклад основного матеріалу.

Освіту розглядають як один із найважливіших чинників соціального розвитку, що методологічно пов' язано з концепціями «єдиного індустріального суспільства», «постіндустріального суспільства», «технотронної ери» тощо. У західній соціології, наприклад, досить поширеною є теза американського соціолога, автора теорії постіндустріального суспільства Д. Белла про те, що рівень здобутої людьми освіти є вирішальною передумовою їх соціального становища [1].

Ідея безперервної освіти посідає одне 3 головних місць серед прогресивних ідей культури XXI ст. Загальнолюдське значення даної ідеї беззаперечне, оскільки суть їі полягає в тому, щоб забезпечити кожній людині постійний стабільний розвиток, удосконалення, творче оновлення протягом усього життя, а отже - забезпечити успішний розвиток суспільства в цілому. Тому держави сьогодні намагаються знайти свою модель безперервної освіти. 
Безперервна освіта розвивалася як феномен практики, а також як педагогічна концепція. Вперше ця ідея була концептуально оформлена та представлена на конференції ЮНЕСКО в 1965 р. видатним теоретиком безперервної освіти П. Ленграндом. На підставі його розробок були сформовані рекомендації з даного питання. У 1972 р. ЮНЕСКО робить наступний крок: відбувається слухання доповіді комісії, яку очолював Е. Фора, на тему «Вчитися, щоб бути». 3 середини 1970$\mathrm{x}$ pр. ідея безперервної освіти знаходить свою підтримку майже в усіх країнах і стає основним принципом освітніх реформ [2].

Найважливішою ідеєю безперервної освіти є розвиток людини як особистості, суб'єкта діяльності та спілкування протягом усього їі життя. Ця ідея, усвідомлена суспільством, стає системоутворюючим чинником безперервної освіти.

Безперервна освіта є всеохоплюючою за своєю сутністю, індивідуальною за часом, темпами та спрямованістю, що дає кожному рівню права та можливості реалізації свого власного потенціалу, отримання знань та поповнення їх протягом усього життя. Формування теоретичних засад безперервної освіти спричинило виникнення галузевих концепцій безперервної освіти. Безперервність та різноманітність освіти $є$ найважливішими принципами реалізації парадигми «освіта через все життя» та забезпечують:

- фундаментальність підготовки, цілісність та спрямованість на особистість студента;

- вільний вибір «траєкторії навчання» та гнучке реагування на ринку інтелектуальної роботи;

- можливість ефективної інтеграції з вузами I - II рівня акредитації;

- широкі можливості післядипломної освіти, створення умов для реалізації прав громадян та потреб країни в постійному розширенні та відновленні професійних і загальноосвітніх знань на базі нових технологій;

- можливість інтеграції до європейських та світових освітніх просторів.

Безперервність освіти реалізується через:

- забезпечення спадкоємності змісту та координації навчально-виховної діяльності на різних рівнях освіти, що функціонують як продовження попередніх та передбачають підготовку осіб до можливого переходу до наступних рівнів, а також перепідготовку та підвищення кваліфікації;

- формування потреб і здібностей особистості до самонавчання;

- створення інтегрованих навчальних планів та програм;

- формування та розвиток учбово-науково-виробничих комплексів багаторівневої підготовки професіоналів;

- оптимізацію системи післядипломної освіти на основі встановлених стандартів вищої освіти;

- створення інтегрованих навчальних планів та програм післядипломної освіти;
• розробка індивідуальних модульних навчальних програм різних рівнів складності залежно від конкретних потреб;

- упровадження і розвиток дистанційної освіти [3].

Освіта протягом життя здійснюється за допомогою трьох видів навчання:

- Формальне навчання (структурна освіта, яка спрямовується на чітко поставлену мету у формі визнаних свідоцтв та дипломів).

- Неформальне навчання - будь-яка освітня діяльність поза формальною системою. Це може бути самоосвітня активність, яка спрямована на отримання додаткових знань, умінь, навичок (результат такого навчання формально не визнається).

- Позаформальне навчання - спонтанне (незапрограмоване навчання у повсякденному житті).

Як свідчить практика, найбільш розвинутим у світі $є$ формальне навчання, яке завершується сертифікацією (видається диплом, свідоцтво тощо), в Україні - атестацією [4].

В основі функціонування безперервної освіти лежать такі принципи, які відображають його специфіку:

- Принцип гуманізму. Свідчить про спрямованість освіти до людини, про свободу вибору особистістю форм, термінів, видів навчання, підвищення кваліфікації, самоосвіти. Даний принцип реалізується через створення сприятливих умов для розвитку творчої індивідуальності кожної людини. Людина розглядається як мета суспільного прогресу.

- Принцип демократизму. Полягає в доступності освіти в будь-якому віці за допомогою різноманітних форм навчання, відповідно до інтересів, можливостей та потреб. Він забезпечує свободу переходу від одного навчального закладу до іншого, прискорене завершення навчання та підвищення кваліфікації. Це гарантує рівні права всіх громадян, незалежно від класової приналежності, національних особливостей, стану здоров'я, на освіту та розвиток. Цей принцип передбачає демократизацію всіх сторін життєдіяльності освітніх закладів, рівноправні відносини суб'єктів педагогічного процесу.

- Принцип мобільності. Проявляється у великому виборі засобів, способів, організаційних форм системи безперервної освіти, їх гнучкості і готовності до стрімкої перебудови відповідно до потреб суспільства, людини.

- Принцип випередження. Опираючись на наукове прогнозування, потребує більш швидкого та гнучкого розвитку, перебудови системи безперервної освіти відповідно до потреб суспільної практики, мобільного оновлення їх діяльності. Даний принцип орієнтується на широке та активне використання нових форм, методів, засобів навчання та перепідготовки фахівців.

- Принцип відкритості системи безперервної освіти. Потребує від навчальних установ розширення діяльності шляхом заохочення до навчання 
та підвищення кваліфікації аудиторії, вільних слухачів. При цьому виникає необхідність працювати 3 різними віковими групами та групами населення, що відрізняються рівнем освіти та професійної підготовки, ставленням до освіти, життєвими устремліннями. Це вимагає створення додаткових факультетів, інститутів, відділень, курсів 3 підвищення освіти і кваліфікації, проведення семінарів. Відкритість навчальних закладів та освітніх систем забезпечується наявністю різних за рівнем, змістом, спрямованістю освітньо- виховних програм.

- Принципи безперервності освіти є систематизуючими. Навчальні установи, працівники освіти та підвищення кваліфікації, науки і виробництва мають переглянути погляди на роль та місце освіти в житті людини і суспільства. Варто подолати орієнтацію на поверхневу «енциклопедичність» змісту, перевантаження інформаційним матеріалом. У змісті освіти мусять знайти відображення проблеми розвитку суспільства, виробництва, науки, культури. Освіта має бути спрямована на розвиток майбутнього. Колишній девіз «Знання на все життя» поступається місцем новому девізу - «Знання через все життя».

У структурі безперервної освіти виділяють дві підсистеми - це основна і додаткова освіта. А в свою чергу, основна і додаткова освіта може бути загальним і професійним. Отже, виходить чотири підсистеми освіти: основна загальна, основна професійна, додаткова загальна, додаткова професійна.

Зв'язок між елементами підсистеми основної освіти будується за принципом ієрархії, кожна наступна ланка надає освіті більш високого рівня. У підсистемі додаткової освіти ланки самостійні та незалежні, вони існують паралельно одна одній. Додаткова освіта не є утворенням більш високого рівня у порівнянні 3 основною. У кожній 3 підсистем є основні та додаткові, основні та паралельні, державні і недержавні навчальні заклади і заклади підвищення кваліфікації, установи культури, спорту, туризму і т. д.

Безперервну освіту потрібно розуміти не як механічний рух особистості від дошкільної до загальної середньої, професійної (початкової підготовка кваліфікованих робітничих кадрів), середньої (підготовка спеціалістів- техніків), вищої (бакалавра, магістра)), післявузівської освіти (аспірантура, докторантура), підвищення кваліфікації, а як гармонійний процес циклічного розвитку особистості на кожному із зазначених етапів. Система безперервної освіти повинна забезпечувати адекватність змісту освіти відповідно до вимог інформаційного суспільства, що динамічно утворюється та розвивається. Саме тому сьогодні більшість освітніх закладів базової освіти організаційно формується у вигляді системи додаткової освіти (курсів додаткових професій, факультетів післядипломної освіти та ін.). Це дозволяє найбільш оптимально вирішувати основні суперечності сучасного етапу суспіль- ного розвитку - між швидкими темпами приросту знань та обмеженими можливостями їхнього оволодіння кожною людиною.

Для безперервної освіти дуже важливим є сворення стратегії інформаційно-інноваційного освітнього середовища, яка забезпечує відкритий доступ до програм навчання різного рівня, розробку та використання основ віртуального навчання як важливого способу розширення доступу до будь-якої освіти - початкової, середньої, професійної, післядипломної. Говорячи про віртуальне навчання, найчастіше мають на увазі здобуття освіти через Інтернет.

Проте це не єдина можливість. Популярними напрямами у галузі віртуальної освіти є навчання та виховання за допомогою використання радіо, TV, преси, різної періодичної літератури, організації відповідних спілкувань, заохочення тих, хто навчається, до професійних товариств та спільнот.

У цьому контексті проблематику безперервної освіти можна умовно розділити на дві основні сфери. Перша пов'язана 3 побудовою системи безперервної освіти як елемента соціальної практики, друга пов'язана 3 процесом засвоєння людиною нового життєвого, соціального, професійного досвіду. Тому наприкінці $90-\mathrm{x}$ років XX століття у галузі освіти дорослих було оголошено поєднання принципу безперервності освіти із принципом навчання протягом життя та формуванням суспільства знань. Тим самим зроблена спроба затвердити у суспільній свідомості усвідомлення взаємної відповідальності суспільства, держави та особистості за розвиток освітніх процесів.

Суттєві труднощі технологічного змісту професійної діяльності, а також стрімкі зміни цього змісту різко реформують характер підготовки людини до необхідних високих теоретичних знань. 3 іншого боку, розширення та ускладнення суспільних зв'язків учасників виробництва не залишаються нейтральними в плані змін психології трудових відносин, що знаходить своє відзеркалення в системі освітніх програм, які направлені на засвоєння загальнокультурної проблематики. У цьому плані перебудова освіти на основі принципу безперервності стає об'єктивною необхідністю, що спричинена логікою та об'єктивними вимогами суспільного життя.

Більшість європейських країн сьогодні реформують власні освітні системи, спираючись на засади концепції навчання впродовж усього життя, що включає такі елементи:

- можливість кожної людини вчитися протягом усього життя;

- доступність для тих, хто навчається, максимально широкого спектру вмінь і навичок (при чому деякі країни доповнюють концепцію освіти протягом життя концепцією безперервної підготовки і ставлять акцент на професійних навичках $\mathrm{i}$ підготовці дорослих); 
- формальна система освіти і підготовки разом із неформальною діяльністю, яка організовується навколо цієї системи, мають бути нероздільними (вони обидві стають предметом уваги і спільної підтримки з боку держави і приватного сектора, особливо що стосується освіти дорослих);

- наголос робиться на сильному фундаменті, який необхідно закласти під час набуття середньої загальної освіти, а також на розвитку прагнення $\mathrm{i}$ мотивації до навчання [5].

Таким чином, модернізація системи освіти вимагає модернізації самої моделі управління цією системою перш за все в контексті інформатизації, залучення інформаційних технологій, які б давали змогу навчатися постійно, часто без відриву від виробництва. Потрібні нові теоретичні розробки, які допомогли б створити модель управління системою вищої освіти, яка б об'єднала або збалансувала елементи централізації та децентралізації, залучала інформаційні технології.

Найбільш складним питанням у безперервній освіті $€$ її фінансування. На сьогоднішній день в основному використовується фінансування 3 різноманітних фондів або організацій, що зацікавлені у підвищенні кваліфікації своїх працівників.

Існує мовчазний консенсус щодо того, що курси повинні бути самооплатними, а оскільки вони розглядаються $з$ позицій «суспільства» та «суспільності», то держава мусить теж робити свій внесок. Але дарма, що безперервна освіта - це, насамперед, соціальне явище, більшість розглядає іiі вигоди лише в фінансовому сенсі, оскільки вони $€$ більш абстрактними, ніж витрати на неї.

Отже, безперервність освіти перебуває в динамічному зв'язку зі соціалізацією особистості. У ході соціалізації людина отримує знання про ті моделі поведінки або мотиви поведінки, які притаманні в даному культурному середовищі.

Людина, проходячи процес соціалізації, не тільки накопичує, але й трансформує ті або інші соціальні явища, процеси, факти для чого очевидна потреба в наявності у неї певних якостей, умінь, навичок. Вона має не тільки усвідомлювати необхідність у такій діяльності, але й бути здатною здійснювати іiі, а тому бути не тільки залученою в загальну культурну підсистему даного співтовариства, але й мати певний рівень знань, творчого мислення, інтелігентності і т. д. Тобто, для перетворення людині потрібен інструмент. Таким інструментом у даному випадку виступає безперервна освіта. Тоді піднімається проблема співвіднесення особистісних потреб в освітній діяльності та затребуваності суспільством тих або інших знань. Останнім часом все більш очевидним стає те, що потреба в освіті вивляється не тільки на рівні окремої особистості, окремої організації, а й суспільства в цілому. Тому такої актуальності набуває сьогодні концепція безперервної освіти, адже навчання протягом усього життя - це не бажання окремої особистості, а необхідна потреба та умова часу як для особистості, так і для суспільства в цілому.

Як засвідчує міжнародна практика та здійснений аналіз у сфері послуг із перепідготовки та навчання персоналу, погіршення економічної ситуації спричинило необхідність випереджального професійного розвитку, формування за допомогою перепідготовки до готовності стрімко та адекватно реагувати на зовнішні умови, своєчасно трансформуватися в перспективні професійні сектори відповідно до умов, що ставить ринкова економіка та економіка «суспільства знань».

Отже, питання безперервної освіти є актуальним як у закордонних, так і в українській системах освіти. 3 метою організації навчання протягом життя в Європі був створений Інститут освіти дорослих. У Європейських країнах безперервна освіта $\epsilon$ важливою частиною державних програм, а також завданням громадських організацій та товариств.

В Україні головну роль у забезпеченні безперервної освіти відіграють інститути післядипломної педагогічної освіти, що потребують модернізації структури та змісту. Перш за все для відкритості системи потрібне широке застосування очно-дистанційної та дистанційної форм навчання та їх навчально-методичний супровід. Тільки за присутності установ безперервної освіти (інститутів, університетів, фундацій, центрів) може бути можливе формування в Україні інформаційного суспільства та розвиненої економіки. Саме тому формування теоретичних, змістових та організаційних основ безперервної освіти повинно розглядатися як домінантне завдання державного значення в Україні.

Важливим $є$ питання створення громадських організацій безперервної освіти в Україні, які $б$ розширювати можливості дорослого населення, у тому числі й педагогів, отримувати знання для забезпечення функціональної грамотності, різнобічного розвитку особистості, задоволення індивідуальних потреб у професійному зростанні по кар'єрним сходинкам.

\section{Висновки.}

В умовах формування суспільства актуалізується питання щодо формування нових моделей освіти, серед яких модель безперервної освіти є однією з найбільш актуальних. Проблематику безперервної освіти можна умовно розділити на дві основні сфери. Перша пов'язана 3 побудовою системи безперервної освіти як елемента соціальної практики, друга пов'язана із процесом засвоєння людиною нового життєвого, соціального, професійного досвіду. У другому випадку дуже важливим є сворення стратегії інформаційно-інноваційного освітнього середовища (інформатизації освіти), яка забезпечує відкритий доступ до програм навчання різного рівня, розробку та використання основ віртуального навчання як важливого способу розширення доступу до будь-якої освіти - початкової, середньої, професійної, післядипломної. 


\section{БІБІЛІОГРАФІЧНІ ПОСИЛАННЯ}

1. Белл Д. Грядущее постиндустриальное общество: Опыт социального прогнозирования / Д. Белл. - M.: Асаdеmia, 1999. - 956 с.

2. Безперервна освіта. - Режим доступу: http://www.users.kpi.kharkov.ua/lre/bde/ukr/iol/13.htm

3. Макєєва О. Безперервна освіта суспільства - запорука майбутнього / О. Макєєва // Режим доступу: http://www. personal-plus/net/206/

4. Меморандум безперервної освіти Свропейського Союзу. - Режим доступу: http://www.europians.org.ua/deyanel.html 5. Пуховська Л. П. Професійна підготовка вчителів на Заході: спільність та розбіжності / Л. П. Пуховська. - Київ: Вища школа, 1997. - 180 с.

6. Noble D. Forces of Production: A Social History of Industrial Automation / D. Noble. - N.Y. : Knopf, 1984. - P. 409. 7. Tehranian M. Global communicationan dintonation relations: changing paradigm sand policies / M. Tehranian // Internationals Journalof Peace Studies. - 1997. - № 2 (1). - P. 39-64.

\section{REFERENCES}

1. Bell, D. (1999). Grjadushhee postindustrial'noe obshhestvo: Opyt social'nogo prognozirovanija [The coming postindustrial society: Experience of Social Forecasting]. Moscow: Academia [in Russian].

2. Bezperervna osvita [Continuing education]. Retrieved from: http://www.users.kpi.kharkov.ua//re/bde/ukr/iol/13.htm [in Ukrainian].

3. Makyeyeva, O. Bezperervna osvita suspilstva-zaporuka maibutnoho [Continuing education of society - the key to the future]. Retrieved from: http://www.personal-plus/net/206/ [in Ukrainian].

4. Memorandum bezperervnoi osvity Yevropeiskoho Soiuzu [Memorandum of Continuing Education of the European Union]. Retrieved from: http://www.europians.org.ua/deyanel.html [in Ukrainian].

5. Pukhovska, L.P. (1997). Profesiina pidhotovka vchyteliv na Zakhodi: spilnist ta rozbizhnosti [Professional teachers training on the West: similarities and differences]. Kyiv: Vyshcha shkola [in Ukrainian].

6. Noble, D. (1984). Forces of Production: A Social History of Industrial Automation. New-York: Knopf.

7. Tehranian, M. (1997). Global communicationan dintonation relations: changing paradigm sand policies. Internationals Journal of Peace Studies, 2 (1), 39-64.

\section{Половая Наталія Олександрівна}

Викладач

Національний авіаційний університет

03680, м. Київ, просп. Космонавта Комарова, 1

\section{Polovaya Natalia $O$.}

Lecturer

National aviation university

1, Komarova Av., Kyiv, 03680, Ukraine

Email: sosonovitch.natalia@ukr.net

Цитування: Половая Н.О. Безперервна освіта як вектор розвитку інформаційного суспільства // Науково-теоретичний альманах «Грані». - 2018. - Т. 21. - № 4. - С. 91-96.

Citation: Polovaya, N.A. (2018). Bezperervna osvita yak vektor rozvytku informatsiinoho suspilstva [Continuing education as a vector of information society development]. Scientific and theoretical almanac «Grani», 21(4), 91-96. 